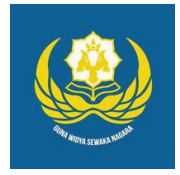

Jurnal Analogi Hukum

Journal Homepage: https://ejournal.warmadewa.ac.id/index.php/analogihukum

\title{
Pertanggungjawaban Terhadap Tindak Pidana Penyelundupan Sepeda Motor Harley oleh Direktur PT. Garuda Indonesia
}

\author{
I Dewa Gede Pramana Adhi*, I Nyoman Gede Sugiartha dan I Made Minggu Widyantara \\ Fakultas Hukum, Universitas Warmadewa, Denpasar, Bali-Indonesia \\ *pramanaadhi75@gmail.com
}

\begin{abstract}
How To Cite:
Adhi, I. D. G. P., Sugiartha, I. N. G., \& Widyantara, I. N. M. (2021). Pertanggungjawaban Terhadap Tindak Pidana Penyelundupan Sepeda Motor Harley oleh Direktur PT. Garuda Indonesia. Jurnal Analogi Hukum. 3 (2). 240-244. Doi: https://doi.org/10.22225/ ah.3.2.2021.240-244
\end{abstract}

\begin{abstract}
Indonesia is a developing country where each region has its own natural wealth. This advantage cannot be utilized because of the number of people who send out of the area without permission and vice versa goods from outside countries smuggled into Indonesi a only to avoid the applicable taxes. 1) What is the regulation of smuggling crimes in indonesian criminal law? 2) What is the accountability of the director of PT. Garuda Indonesia who carried out the act of smuggling luxury motorcycles? This research is a type of normative law research conducted by a research method of reviewing based on legal materials, while the problem approach used is the approach of legislation - legislation and conceptual. A bad example was again shown by one of the people who have a big name in Indonesia smuggling case by garuda Indonesia dirut become a picture of how weak the law in Indonesia and this incident makes the perpetrator can be criminal and administrative sanctions.
\end{abstract}

Keywords: Criminal; Smuggling; Performer.

\begin{abstract}
Abstrak-Indonesia merupakan negara berkembang dimana setiap wilayahnya terdapat kekayaan alam tersendiri. Keunggulan ini tidak dapat dimanfaatkan karena banyaknya oknum yang mengirim keluar daerah tanpa izin begitupun sebaliknya barang dari negara luar yang diselundupkan ke Indonesia hanya untuk menghindari dari pajak yang berlaku. 1) Bagaimanakah pengaturan tindak pidana penyelundupan dalam hukum pidana di Indonesia? 2) Bagaimanakah pertanggungjawaban direktur PT. Garuda Indonesia yang melakukan tindakan penyelund upan sepeda motor mewah? Penelitian ini merupakan tipe penelitian hukum normatif yang dilakukan dengan metode penelitian mengkaji berdasarkan bahan-bahan hukum, sedangkan pendekatan masalah yang digunakan adalah pendekatan peraturan perundang-undangan dan konseptual. Contoh buruk kembali diperlihatkan oleh salah satu orang yang punya nama besar di Indonesia kasus penyelundupan oleh dirut garuda Indonesia menjadi gambaran betapa lemahnya hukum di Indonesia dan kejadian ini membuat pelaku dapat sanksi pid ana dan administratif.
\end{abstract}

Kata Kunci: Pidana; Penyelundupan; Pelaku.

\section{Pendahuluan}

Indonesia merupakan negara yang wilayahnya terdiri dari beberapa pulau mambuat mempermudah berbagai kegiatan ilegal dapat dilakukan dengan pengawasan yang tidak begitu ketat, beberapa kali barang ilegal masuk tanpa diketahui sektor keamanan namun sering ka li tertangkap basah. Jarak antara pulau yang berbeda-beda membuat semakin banyaknya oknum tertentu dapat melakukan tindakan yang bertentangan dengan hukum positif yang berlaku. Baik dari jalur darat, udara atau laut, yang amatir maupun yang memiliki jabatan kasus penyelundupan tidak ada hentinya di Indonesia. Yang terbaru penyelundupan sepeda motor mewar oleh orang yang memiliki jabatan di salah satu maskapai penerbangan. Seperti tanpa beban dan malu dengan leluasanya orang yang memiliki jabatan berbuat seenaknya tanpa memikirkan konsekuensi dari perbuatannya. Berasal dari luar negara 
Indonesia sepeda motor mewah tersebut tanpa pemeriksaan sampai di Jakarta dan apesnya pengecekan di dilakukan di Jakarta dan terbukti bahwa bagian-bagian sepeda motor mewah tersebut sebanyak 17 kotak terpisah dan tanpa nama sudah masuk Indonesia. (Lopa. 1983)

Banyak orang menyayangkan kejadian tersebut karena sebelum kejadian tersebut baru saja terjadi penyelundupan satwa langka di Indonesia. Kejadian seperti ini $\mathrm{s}$ ering terjadi namun tidak semua diliput oleh media hanya karena pelakunya kali ini merupakan orang yang memegang jabatan di Garuda Indonesia makanya dipublikasikan dan membuat banyak masyarakat heboh. Disatu sisi kejadian disayangkan masyarakat karena pelaku merupakan orang yang berkecukupan dan dapat dikatakan orang kaya disisi lain banyak masyarakat atau oknum tertentu menjadikan kejadian ini sebagai motivasi atau ajang unjuk gigi karena orang yang memegang kuasa saja bisa kenapa kita yang orang tidak dipandang tidak bisa melakukan perbuatan yang sama yang nantinya tidak akan ada media yang meliput karena bukan orang penting.

Pelanggaran hukum positif di Indonesia di bidang penyelundupan sering sekali terjadi dan banyak pertanyaan dari masyarakat apakah hu kum di Indonesia hanya sekedar wacana belaka atau pihak yang menyelundupkan barang lebih cerdas ketimbang para penegak hukum. Seperti mati satu tumbuh seribu kejadian penyelundupan ini sudah tidak bisa dihitung jari dan pemerintah sampai memperketat sektor udara, lautan guna menanggulangi tindak pidana penyelundupan yang ada. Pemerintah bekerja sama dengan pihak keamanan dengan membuat peraturan mengenai sanksi yang dapat membuat efek jera bagi pelaku penyelundupan. Selain membuat peraturan mengenai efek je ra bagi pelaku pemerintah juga harus memikirkan tindakan pencegahan yang dapat menggagalkan tindakan oknum yang akan menyelundupkan barang ilegal.

Penyelundupan merupakan tindakan yang dilarang keras oleh pemerintah dan sudah ada peraturan perundang-undangan yang mengatur sanksi bagi siapa saja yang sengaja melakukan penyelundupan baik keluar negara maupun ke dalam negara namun banyak oknum yang tidak memperdulikan karena melihat dari sisi pendapatan atau hasil yang diperoleh setelah berhasil menyelundupkan barang tersebut membuat semakin maraknya kasus penyelundupan ditambah saat ini susahnya mencari pekerjaan membuat banyak oknum berpikir dengan jalan pintas untuk mendapatkan hasil dengan waktu yang singkat tanpa harus mematuhi hukum positif yang berlaku. Penegak hukum dalam menangani kasus penyelundupan lebih ditingkatkan dan dilakukan tindakan dini guna memotong jalur penyelundupan sebelum kejadian disatu sisi demi mengurangi hutang negara dan membuat baik nama penegak hukum yang sudah dianggap masyarakat tidak mampu mengantisipasi dan mengakhiri kasus penyelundupan yang terjadi.

Sektor yang menjadi target penyelundupan barang impor adalah bandara, sangat sering pelaku mengelabui dengan menyisipkan barang impor di sela-sela barang penumpang lainnya yang membuat sulit dideteksi tentu yang dilakukan tidak hanya itu biasanya pelaku sudah menjalin kerja sama dengan orang dalam bahkan pelakunya merupakan pekerja di bandara tersebut untuk memastikan barang aman sampai keluar bandara. Kasus yang barubaru ini terjadi ialah penyelundupan motor harley davidson yang dilakukan oleh direktur PT. Garuda Indonesia yang dibawa dari Prancis. Dapat dipastikan Direktur PT. Garuda Indonesia melanggar hukum positif yang ada di Indonesia dan pelanggaran karena telah menyalahgunakan wewenang yang dipegangnya. Kejadian yang seperti ini membuat pihak maskapai dan pihak bandara menambah ekstra pengawasannya agar kejadian serupa tidak terulang kembali.

Banyak masyarakat mempertanyakan kenapa sampai melakukan hal seperti itu jawabannya karena ingin mendapat keuntungan yang besar dari hasil penjualan sepeda motor tersebut atau akan lebih he mat biaya jika kemudian sepeda motor itu dijadikan kendaraan pribadi. Dalam surat Keterangan Menteri Perindustrian dan Perdagangan Nomor.229/ MPP/Kep/7/1997, pasal 3 Ketentuan Umum dibidang impor memang disebutkan bahwa barang yang impor harus dalam keadaan baru kecuali kapal niaga dan kapal ikan . Dalam keputusan tersebut juga disebutkan bahwa, impor hanya boleh dilakukan oleh perusahaan yang telah memiliki Angka Pengenal Importir (API) atau API -Terbatas : Motor Harley Davidson tersebut bebas dari biaya bea dan cukai sehingga dikatakan impor ilegal. Hal ini tentu menimbulkan perekonomian yang tidak sehat dan mengakibatkan kerugian Negara. Dengan demikian jelas bahwa masuknya barang tersebut ke Indonesia tidak melalui prosedur sebagaimana disebutkan dalam kebijaksanaan umum dibidang impor sehingga hal tersebut merupakan pelanggaran hukum dibidang ekonomi yaitu pelanggaran yang lebih dikenal dengan sebutan penyelundupan (Alam, 2010). 


\section{Metode}

Penelitian ini dilakukan dengan mencari data melalui buku ilmu hukum dan menghubungkan dengan permasalahan yang diangkat kemudian mengkaitkan dengan perundang-undangan yang berlaku saat ini. Dari segi hukum penelitian ini termasuk penelitian normatif.

Penulis mengkaitkan dengan peraturan yang berlaku dan tidak menyimpang dari undang-undang dasar. Pendekatan penelitian dengan cara mengkaji, mencari dan memilah data dari berbagai buku hukum dan berpatokan pada undang-undang sebagai dasar penulisan skr ipsi. Penelitian ini bertujuan mencari informasi yang akurat dengan mempelajari gejala masyarakat untuk mendapatkan data yang sebenar-benarnya. Dengan demikian data dapat digabungkan dengan berbagai referensi buku hukum yang terkait dan menghasilkan skri psi yang tidak melenceng dari hukum positif. (Ahmad, 2008).

Penulis meneliti kasus ini menggunakan metode normatif. Dimana dalam pengerjaannya penulis mengumpulkan informasi dengan menelaah dan menganalisa buku-buku hukum yang didasari peraturan-peraturan hukum yang berlaku di Indonesia.

\section{Hasil dan Pembahasan}

\section{Pengaturan Tindak Pidana Penyelundupan Dalam Hukum Pidana Di Indonesia}

Penyelundupan adalah suatu istilah yang dapat kita temukan dalam kehidupan seharihari, yang masyarakat umumnya mengartikan sebagai suatu perbuatan pidana yang melanggar suatu peratura $\mathrm{n}$ mengenai pemasukan atau pengeluaran barang dari luar Negeri. Penyelundupan atau yang dalam bahasa Belandanya smokkel dan bahasa Inggrisnya smuggling adalah: mengimpor, mengekspor, mengantar pulaukan barang yang berlaku atau tidak memenuhi formalitas pabean yang ditetapkan oleh Undang-Undang. Hakikat dari pada penyelundupan adalah menghindari bea masuk/bea keluar supaya mendapatkan keuntungan yang lebih besar, menghindari larangan pemerintah untuk memasukkan barang -barang tertentu yang dilarang oleh pemerintah untuk dimasukkan ke Indonesia.

Pada penyelundupan impor, perbuatan ini dilakukan karena adanya perbedaan yang cukup besar antara harga barang di luar Negeri dengan harga didalam negeri sehingga mengakibatkan orang berusaha untuk menyelundupkan barang tersebut dari luar Negeri kedalam Negeri. Disamping itu ada kemungkinan bahwa barang tersebut diselundupkan masuk ke Indonesia karena barang tersebut di luar Negeri sudah tidak dipakai lagi sehingga harganya sangat murah atau bahkan tidak dapat diperjual belikan lagi karena dianggap limbah. Jadi orang yang memasukkan barang tersebut akan mengharapkan keuntungan yang sangat besar karena hanya membeli dari pen gumpul dengan harga murah ditambah dengan biaya angkut, sementara barang-barang bekas tersebut dilarang untuk dimasukkan ke Indonesia. Dengan demikian akan diperoleh suatu keuntungan yang sangat besar apabila barang tersebut dapat dimasukkan ke dalam Negeri dan dijual dengan harga yang tinggi (Hartono, 1994).

Pengertian dari beberapa pendapat diatas disimpulkan penulis sebagai pelanggaran hukum positif oleh oknum-oknum tertentu yang dengan keperluan pribadi mencari keuntungan tersendiri dengan memperjualbelikan barang yang dilanggar diperjualbelikan atau barang yang dikenakan pajak oleh negara keluar negara dan begitu sebaliknya. Dalam ketentuan mengenai barang yang dilarang dapat dikenakan sanksi berat bagi yang dengan sengaja menyelundupkan ba rang demi terhindar dari biaya administrasi atau pajak yang berlaku di Indonesia

Penyelundupan sendiri terdiri dari dua jenis yaitu secara impor dan secara ekspor dimana keduanya memiliki kesamaan arti namun dari segi pengirimannya yang berbeda dan dapat d ijabarkan sebagai berikut:

1. Penyelundupan impor merupakan jenis penyelundupan barang yang masuk ke dalam negeri, dengan pesaran dari oknum tertentu menggunakan jalur laut, darat, atau udara tanpa mengikuti prosedur pengiriman barang yang ada dan informasi yang tertera berbeda dengan barang yang dikirimkan

2. Penyelundupan Ekspor sendiri kebalikan daripada penyelundupan impor dimana pengiriman barang melalui jalur laut, darat dan udara melalui Indonesia ke luar negara tanpa mengikuti ketentuan yang berlaku

Selain penyelundupan diatas terdapat beberapa jenis penyelundupan lainnya yaitu secara Legal dan Ilegal dibedakan menjadi dua jenis karena ada beberapa jenis barang yang diijinkan pengirimannya ke luar Indonesia namun dengan kelengkapan dokumen dan surat dari pemerintah. Penyelundupan Legal merupakan pengiriman barang dari dalam 
negeri menuju luar negeri dengan urusan kenegaraan dan barang tersebut telah diketahui oleh dua negara atau lebih yang melakukan transaksi dengan mengikuti prosedur semisal dokumen peng iriman dan surat jalan yang berlaku sampai barang tersebut sampai di negara yang dituju. Penyelundupan Ilegal sendiri penyelundupan yang isi dan dokumen pelengkapnya tidak sesuai bisa dikatakan barang tersebut disamarkan atau diselipkan ke dalam barang lain lalu dikirimkan guna terhindar dari jeratan hukum yang berlaku mengenai penyelundupan. Akibat yang diberikan jika barang ilegal ini diketahui bagi negara dapat dikenakan denda sesuai dengan negara tujuan pengiriman barang dan bagi pelaku dikenakan sanksi pidana maksimal seumur hidup dan sanksi administratif yang nantinya akan dipergunakan untuk kebutuhan atau pembangunan infrastruktur negara sesuai dengan ketentuan undang-undang yang berlaku. Di tingkat pemerintahan lebih terkenal dengan penyelundupan fisik dan penyelundupan administratif dengan penjelasan sebagai berikut:

\section{a. Penyelundupan Fisik}

Fisik disini diartikan barang tersebut berbeda dengan isi daripada barang yang dikirimkan dan mencangkup ekspor impor secara sengaja dengan tujuan demi mendapatkan keuntungan tersendiri dan terbukti melakukan tindakan yang berujung merugikan negara. Sanksi pidana diberikan kepada pelaku sebagai efek jera agar kedepan tidak melakukan hal serupa.

\section{b. Penyelundupan Administratif}

Penyelundupan yang bersifat rapi. Rapi disini segalanya telah dipersiapkan secara matang mulai dari izin dan dokumen pendukung yang membenarkan isi daripada barang tersebut namun pada kenyataannya tidak. Kepalsuan yang dibuat oknum cerdik ini semata-mata melancarkan penyelundupan ke negara lain atau sebaliknya dengan membungkus barang ke dalam barang lainnya agar tidak dicurigai sebagai barang yang dilarang diperjualbelikan.

\section{Pertanggungjawaban Direktur PT. Garuda Indonesia Yang Melakukan Tindakan Penyelu Ndupan Sepeda Motor Mewah}

Pertanggungjawaban pidana sendiri merupakan hasil yang diterima dan suka tidak suka harus dijalani atas akibat karena telah melakukan perbuatan yang melanggar ketentuan hukum yang berlaku di Indonesia.
Sanksi diberikan kepada siapa saja dan tidak pandang usia dan golongan selama seseorang melanggar ketentuan pasti mendapat sanksi. Dengan memperhatikan etika, norma dan motif daripada pelaku pemerintah secara konsisten memberikan hukuman bagi yang melanggar ketentuan. Sudah menjadi kewajiban seseorang untuk mempertanggungjawabkan apa yang telah diperbuat karena sebelum melakukan tindak kejahatan seseorang dapat terlebih dahulu memikirkan sebab akibat dari perbuatan yang akan dikerjakannya. Selain memikirkan sebab akibat pikirkan juga keadaan lingkungan dan keadaan keluarga agar tidak terjadi hal yang membuat nama baik keluarga menjadi tercemar.

Penjatuhan hukuman bagi tersangka penyelundupan barang ilegal harus mengikuti unsur yang berlaku dan tetap memandang hak asasi manusia yang ada pada diri tersangka. Perbuatan melanggar ketentuan perundangundangan harus diadili guna memberi efek jera bagi oknum lain yang akan melakukan perbuatan yang sama. Dalam proses pemberian hukuman aturan tentang aparat negara juga diberlakukan dan dilaran $\mathrm{g}$ bertindak diluar hukum positif yang berlaku. Tindakan pra peradilan sepenuhnya diberikan kepada pihak kepolisian untuk mengetahui dan mencari motif pelaku dan menyaring informasi jika pelaku memiliki jaringan penyelundupan lainnya agar dapat dilakukan pe ncegahan sedini mungkin sebelum menimbulkan perbuatan yang dapat merugikan negara.(Santoso, 2001).

Teori Upaya Penanggulangan Kejahatan (Criminal Prevention)

\section{Pre-Emtif}

Tindakan ini dilakukan sebelum terjadinya tindak kejahatan dalam tugasnya sebagai kepolisian wajib melaksanakan tindakan ini demi mencegah timbulnya korban maupun kerugian yang dialami masyarakat banyak maupun negara. Norma-norma yang ada dalam diri seseorang diuji disini dimana dalam tindakan pre -emtif seorang petugas kepolisian harus pandai memprediksi kemungkinan yang akan terjadi pada sebuah kasus tindak kejahatan. Dalam kasus penyelundupan pihak kepolisian bekerja sama dengan masyarakat atau intel (polisi berpakaian preman) untuk menelusuri penyelundupan kapan, dimana dan bagaimana akan terjadi penyelundupan. Dalam kasus penyelundupan sepeda motor mewah ini pihak kepolisian seharusnya bekerjasama dengan polisi tempat akan terjadinya penyelundupan dan menahan pelaku sebelum terjadinya pengiriman sepeda motor mewah 
menuju Indonesia.

\section{Preventif}

Dalam tindakan preventif dapat dikatakan sebagai tindakan mengantisipasi dimana objek yang akan diselundupkan sudah diamankan terlebih dahulu diamankan oleh $\mathrm{k}$ epolisian. Fokus tindakan preventif disini untuk menemukan pihak atau oknum yang berencana melakukan penyelundupan guna menyaring pelaku dari tindakan tersebut dan mencegah terjadinya kerugian negara.

\section{Represif}

Tindakan ini berfokus pada penangkapan dan pemberian hukuman bagi pelaku tindak pidana. khusus untuk kasus penyelundupan sepeda motor pihak kepolisian menyerahkan pelaku untuk ditindaklanjuti di meja hijau proses ini sering disebut sebagai law enforcement atau pemberian sanksi.

\section{Simpulan}

Pengaturan tindak pidana penyelundupan di Indonesia terdapat dalam Undang-Undang Nomor 17 Tahun 2006 Tentang Kepabeanan. Penanganan atas pelanggaran ketentuan kepabeanan lebih dititik beratkan pada penyelesaian secara fiscal yakni berupa pembayaran sejumlah uang kepada Negara dalam bentuk denda. Dalam hal ini merupakan pengaruh era globalisasi yang menuntut kecepatan dan kelancaran arus barang bagi kemajuan perdagangan nasional dan internasional. Undang-undang kepabeanan sendiri telah memberi aturan dan kemudahan dalam melakukan kegiatan ekspor impor serta memberi kepercayaan yang besar pada pengguna jasa kepabeanan. Namun kepercayaan tersebut harus diimbangi dengan tanggung jawab, kejujuran, dan kepatuhan dalam pemenuhan ketentuan Undang-undang yang berlaku, sehingga apabila pengguna jasa kepabeanan dalam rangka pemenuhan kewajiban kepabeanan melakukan tindakan yang tidak sesuai dengan ketentuan yang diwajibkan oleh Undang -undang Kepabeanan maka akan diatur bagaimana pemberian sanksi bagi mereka yang melanggar tersebut.

Pertanggungjawaban pidana terhadap penyelundupan motor harley davidson yang dilakukan oleh direktur PT. Garuda Indonesia yang dibawa dari Prancis menambah banyaknya kasus tindak pidana penyelundupan yang terjadi di Indonesia. Perbuatan Direktur PT. Garuda Indonesia melanggar hukum positif yang ada di Indonesia dan pelanggaran karena telah menyalahgunakan wewenang yang dipegangnya. Dalam pengaturan UndangUndang Nomor 17 Tahun 2006 direktur utama PT. Garuda Indonesia terancam sanksi pidana dan administratif.

\section{Daftar Pustaka}

Ahmad, B. (2008). Metode Penelitian. Bandung: Pustaka Setia.

Alam, A. S. (2010). Pengantar Kriminologi. Surabaya: Pustaka Refleksi Books.

Hartono, S. (1994). Penelitian Hukum di Indonesia pada Akhir Abad ke-20. Bandung: PT. Alumni.

Lopa, B. (1983). Tinjauan Yuridis Pelapor Dalam Tindak Pidana. Jakarta: Damai Jaya.

Santoso, T. (2001). Ilmu Hukum Pidana. Jakarta: Rineka Cipta. 